\title{
Evaluating Performance of Maize hybrids in Terai Region of Nepal
}

\author{
Chitra Bahadur Kunwar*, Jiban Shrestha \\ Nepal Agricultural Research Council, National Maize Research Program, Rampur, Chitwan, Nepal \\ *Corresponding author: chitra2058@yahoo.com \\ Received February 09, 2014; Revised February 18, 2014; Accepted February 24, 2014
}

\begin{abstract}
The replacement of open pollinated varieties by hybrids is an effective way to increase the maize production. The access to hybrid maize is very limited for Nepalese farmers. In order to identify high yielding maize hybrids, eighteen maize hybrids were tested under coordinated varietal trial using randomized complete block design in two replicates in 2007/08 to 2008 /09 during winter seasons at National Maize Research Program, Rampur, Chitwan, Nepal. The results showed that, among studied traits, hybrids exhibited significant differences for tasseling, silking and grain yield in both years. The hybrid namely L3/L2 produced the highest grain yield (7.2 t/ha) followed by L1/L3 (6.4 t/ha) and P UTU-20/AG-27 (5.9 t/ha), respectively. The results indicated that these hybrids were promising; they should be tested under on-farms and promoted for general cultivation in Terai region of Nepal.
\end{abstract}

Keywords: maize hybrid, grain yield and winter season

Cite This Article: Chitra Bahadur Kunwar, and Jiban Shrestha, "Evaluating Performance of Maize hybrids in Terai Region of Nepal." World Journal of Agricultural Research, vol. 2, no. 1 (2014): 22-25. doi: 10.12691/wjar-2-1-4.

\section{Introduction}

Maize (Zea mays L.) is the most important crops in the world; it is used mainly for human food, animal feed and industry. It is the second staple food crop for country and first staple food crop for hill regions of Nepal. In Nepal, it is the food for more than 14 million people in the hills and is playing a vital role in the livelihood of rural people. In the changing climatic context, maize will be a leading and life saving crop in Nepal. The productivity of maize in Nepal is very low. Total area under cultivation of maize in Nepal is 870166 ha, which is about $28.15 \%$ of the total cultivated agricultural land while average yield is $2.15 \mathrm{t} / \mathrm{ha}$. It is about $23.28 \%$ of the total cereal production and $6.87 \%$ to Agricultural Gross Domestic Product in Nepal (MOAC, 2007/08). It is well recognized fact that cultivation of hybrids maize cultivars is one of the best alternatives to increase the production and productivity of maize in Nepal. Hybrid maize after rice is being popular among the famers of central and eastern Terai. It also indicates the changing scenario of farmers' preferences towards maize after rice. Most of the winter maize produced in Terai and inner Terai districts is utilized as the raw materials for the poultry feed industries. The everincreasing trend of poultry business has demanded considerably more amounts of maize grains. Only the cultivation of open pollinated varieties in spring or summer season could not meet the demand of maize grains in the market. Farmers in the boarder districts adjoining to India has been trying to supply maize grains for those industries through growing hybrid maize cultivars since many years. They are also exploiting hybrid maize as green cobs near to road corridor as cash crop. Thus, hybrid maize has become one of the potential options to fulfill the market demand.

Due to unavailability of hybrid maize as seed, majority of farmers are still growing open pollinated varieties (OPVs) in the Terai region of Nepal. There is a huge potentiality of doubling the current national average yield of maize through exploitation of heterosis. Multi Terai and inner Terai of Nepal is highly potential for hybrid cultivation particularly in spring and winter seasons (Sharma et al., 2004). Hybrid maize breeding in Nepal was initiated since 1987 however, there was no hybrids for farmers except Gaurav released in 2003. This historical hybrid maize cultivar could not become popular among the maize growers due to some constraints in seed production as demanded by the consumer. It shows that farmers have not any varietal options in case of hybrids maize for general cultivation. Therefore this study was conducted at National Maize Research Program, Rampur, Chitwan in 2007/08 to 2008/09 during winter seasons in order to identify high yielding superior hybrids for Terai region of Nepal.

\section{Materials and Methods}

\subsection{Genetic Materials and Experimental Site}

Eighteen maize hybrids namely P UTU-10/Rampur Composite, L3/L2, P UTU-9/AG-27, PUTU-2/Rampur Composite, L2/L1, P UTU-19/AG-27, AG-29/Pool-17, PUTU-17/AG-27, PUTU-12/AG-27, PUTU-10/Arun-2, 
L1/L3, L7/L6, AG-20/Pool-17, PUTU-20/AG-27, PUTU4/Rampur Composite along with three check hybrids; Gaurav, Rajkumar, P ioneer30G10 were used in these experiments. The geographical location of the trials was 27o 37' N latitude, 84o 25' E longitude at an altitude of 256 meter above sea level and has a sub tropical climate (Thapa and Dangol, 1988).

Table 1. Meteorological data during trials (from September 2007 to December 2009 Februrary) at National Maize Research Program, Rampur, Chitwan, Nepal

\begin{tabular}{ccccc}
\hline Month & Average maximum temperature $\left({ }^{\circ} \mathrm{C}\right)$ & Average minimum temperature $\left({ }^{\circ} \mathrm{C}\right)$ & Ra infall $(\mathrm{mm})$ & Re lative humid ity $(\%)$ \\
\hline September (2007) & 32.5 & 24.38 & 926.7 & 89.3 \\
October & 32.3 & 21.4 & 120.2 & 89.5 \\
November & 29.7 & 13.8 & 4.6 & 92.2 \\
Dece mber & 24.4 & 8.9 & 0 & 99.6 \\
January (2008) & 22.3 & 8.48 & 17.1 & 74.91 \\
February & 24.3 & 7.64 & 1.7 & 96.24 \\
September & 33.1 & 24.3 & 218.7 & 86.8 \\
October & 31.4 & 19.7 & 87.3 & 89.4 \\
November & 28.2 & 13.7 & 0 & 94.7 \\
Dece mber & 23.9 & 12.1 & 0 & 97.5 \\
January (2009) & 23.4 & 10 & 0 & 98.6 \\
February & 27.8 & 10.2 & 0.1 & 93.5 \\
Ave rage & 27.78 & 14.55 & 1376.40 (total) \\
\hline
\end{tabular}

\subsection{Experimental Design and Crop Husbandry}

The trials were conducted under coordinated varietal trial at the National Maize Research Program, Rampur, Chitwan, Nepal during September to February, 2007/082008/09. The experimental design was randomized complete block design (RCBD) with two replications in both years. The plot size was 4 rows of $5 \mathrm{~m}$ length with spacing of $75 \mathrm{~cm} \times 25 \mathrm{~cm}$ (RR x PP) and all plots were fertilized with 160:60:40 N $: \mathrm{P}_{2} \mathrm{O}_{5}: \mathrm{K}_{2} \mathrm{O} \mathrm{kg} / \mathrm{ha}$ in the form of urea, di-amonium phosphate (DAP), and murate of potash (MoP). Of this $50 \%$ of nitrogen, full $100 \%$ of phosphorous and potassium fertilizers were applied as basal and remaining $50 \%$ of nitrogen was split first at knee high stage (top dressing) and second at tasseling stage (side dressing). Thinning was done at $25^{\text {th }}$ day after sowing (DAS) to maintain a single plant per hill. Furadon (3 \% C.G) 2-3 granules per plant of maize was applied against the stem borer to the uppermost whorls of leaves at the grand growth stage (40 DAS). Two manual weedings were done throughout the maize growing period, first at knee-high (25 DAS) and second at tasseling stage (55 DAS). Irrigations was done two times during the growing period of maize hybrids, first at grand growth stage (40 DAS) and second at tasseling stage (60 DAS).

\subsection{Data Recording, Measurements and Analysis}

The observation on days to $50 \%$ tasseling, days to $50 \%$ silking, plant height, ear height and grain yield was taken. Ten plants in each subplot (harvested plot) after harvesting were randomly selected; their ear lengths were measured with the help of measuring tap. The data generated were averaged to record ear length. Ears harvested for grain yield were used for the determination of number of grains/ear by selecting ten ears randomly from each subplot, dried (around 15\% moisture) and shelled (80\% shelling) for grains/ear. Data regarding thousand grains weight were recoded by counting randomly selected 1000 grains from each sub plot and weighed with sensitive electronic balance. The grain yield (kg/ha) was recorded by weighing the grains shelled from the ears obtained from the central four rows of each subplot and converted it into $\mathrm{kg} / \mathrm{ha}$ using the formula:

$$
\begin{aligned}
& \text { Grain yield }(\mathrm{kg} / \mathrm{ha}) \\
& =\left\{\text { Grain yield }(\mathrm{kg}) / \text { Area harvested }\left(7.5 \mathrm{~m}^{2}\right)\right\} \text { x10000 }
\end{aligned}
$$

Data were analyzed using the statistical package MSTAT-C (Russel and Eisensmith, 1983) and the significant differences between treatments were determined using least significant difference (LSD) test at probability level of 0.01 or 0.05 where the effects of the treatments were significant at $1 \%$ or $5 \%$ level of probability, respectively.

\section{Results and Discussion}

Flowering is important factor contributing to grain formation in maize. In 2007/08, days to 50\% tasseling ranged from 54-78 days which was significantly different. Similarly in second growing season (2008/09 winter), it ranged from 52-66 days which was significant. The days to $50 \%$ silking varied from 54-76 days that was significant different in 2007/08 winter. In 2008/09, it was observed from 55-70 days that was significant.

Plant height is a genetically as well as environmentally controlled factor and different hybrids have different plant height. In 2007/08, the height of the plants was ranged from 152-225 cm and mean height is $195 \mathrm{~cm}$. Similarly, in 2008/09, plant height differed from 130- $207 \mathrm{~cm}$ and mean height $178 \mathrm{~cm}$. These results are in accordance with the results of Ali (1994) who also reported difference of plant height in different hybrids. This was due to the fact that plant height is a genetically controlled factor so the height of different varieties does not remain equal. As for the effect of environmental factors on plant height is concerned it could not be neglected but the selection of proper crop cultivar manages the influence of environment. 
Ear height is one of the most desirable traits in maize. Positioning of the ear above the middle of the plants often leads to lodging. The ear height of tested hybrids varied from 97-120 cm which was non-significant level on 2007/08 winter. Similarly in 2008/09 winter, the ear height was observed from 62-100 cm which was not significant.

Grain yield of a crop is the ultimate objective of all the research of grain crops. Data in the table indicated that maize hybrid varied significantly for grain yield. The analysis revealed that hybrids differ for grain yield and other traits (Table 2 and Table 3). The hybrids PUTU19/AG-27, PUTU-20/AG-27, Gaurav, L-3/L-2, L-1/L-3 and P UTU-9/AG-27 produced highest grain yield 12.911,10.175, 8.618, 7.205, 6.391 and 5.572 t/ha respectively. These results are in line with those of McCutcheon et al. (2001), who reported significant differences among maize cultivars for grain yield.

Table 2. Agronomic performance of maize hybrids at National Ma ize Research Program Rampur, Chitwan, Nepal in 2007/08 winter season

\begin{tabular}{|c|c|c|c|c|c|c|}
\hline S.N. & Hy brids & 50\%Tasseling day s & $50 \%$ Silk in g day s & Plant height $(\mathrm{cm})$ & Ear height $(\mathrm{cm})$ & Grain y ield (t/ha) \\
\hline 1 & PUT U-10/Ra mpur Co mpos ite & 68.0 & 71.0 & 205.0 & 100.0 & 6.0 \\
\hline 2 & L3/ L2 & 73.5 & 76.5 & 180.0 & 100.0 & 8.4 \\
\hline 3 & PUT U-9/A G-27 & 73.0 & 76.0 & 210.0 & 107.5 & 6.5 \\
\hline 4 & PUT U-2/ Ra mpur Co mpos ite & 68.5 & 71.5 & 220.0 & 112.5 & 6.5 \\
\hline 5 & L2/ L1 & 67.0 & 70.0 & 220.0 & 120.0 & 8.5 \\
\hline 6 & PUT U-19/A G-27 & 77.0 & 80.0 & 205.0 & 110.0 & 12.9 \\
\hline 7 & AG-29/Pool-17 & 65.0 & 68.0 & 225.0 & 110.0 & 7.1 \\
\hline 8 & PUT U-17/A G-27 & 78.5 & 81.5 & 210.0 & 110.0 & 7.8 \\
\hline 9 & PUT U-12/A G-27 & 78.0 & 81.0 & 152.5 & 90.0 & 7.3 \\
\hline 10 & PUT U-10/Arun-2 & 64.5 & 67.5 & 195.0 & 97.5 & 6.0 \\
\hline 11 & L1/ L3 & 78.5 & 82.0 & 200.0 & 100.0 & 6.6 \\
\hline 12 & L7/ L6 & 75.5 & 78.5 & 152.5 & 92.5 & 5.6 \\
\hline 13 & AG-20/Pool-17 & 54.5 & 57.5 & 190.0 & 95.0 & 6.7 \\
\hline 14 & PUT U-20/A G-27 & 70.0 & 73.0 & 170.0 & 92.5 & 10.2 \\
\hline 15 & PUT U-4/ Ra mpur Co mpos ite & 67.0 & 70.0 & 215.0 & 112.5 & 6.4 \\
\hline 16 & Gaurav & 76.0 & 79.0 & 200.0 & 97.5 & 8.6 \\
\hline 17 & Ra jku ma r & 72.0 & 76.0 & 205.0 & 100.0 & 4.1 \\
\hline \multirow[t]{5}{*}{18} & Pioneer30G10 & 76.0 & 79.0 & 165.0 & 92.5 & 5.8 \\
\hline & Grand mean & 71.25 & 74.333 & 195.556 & 102.222 & 7.279 \\
\hline & $\mathrm{CV}, \%$ & 5.08 & 5.01 & 12.99 & 15.10 & 24.29 \\
\hline & F-tes $t$ & $*$ & $*$ & ns & ns & $*$ \\
\hline & LSD0.05 & 7.638 & 7.861 & 53.600 & 32.565 & 3.730 \\
\hline
\end{tabular}

Table 3. Agronomic performance of maize hybrids at National Ma ize Research Program, Rampur, C hitwan in 2008/09 winter season

\begin{tabular}{|c|c|c|c|c|c|c|}
\hline \multicolumn{2}{|c|}{ S.N. Hybrids } & \multirow{2}{*}{$\frac{50 \% \text { Tasseling days }}{52.5}$} & \multirow{2}{*}{$\frac{50 \% \text { Silking days }}{56.5}$} & \multirow{2}{*}{$\frac{\text { Plant height }(\mathrm{cm})}{160.0}$} & \multirow{2}{*}{$\frac{\text { Ear height }(\mathrm{cm})}{80.0}$} & \multirow{2}{*}{$\frac{\text { Grain yield (t/ha) }}{4.3}$} \\
\hline 1 & PUTU-10/Ra mpur Composite & & & & & \\
\hline 2 & L3/L2 & 60.5 & 64.0 & 192.5 & 95.0 & 7.2 \\
\hline 3 & PUTU-9/A G27 & 60.0 & 63.0 & 180.0 & 100.0 & 5.6 \\
\hline 4 & PUTU-2/Rampur Composite & 61.5 & 64.5 & 197.5 & 92.5 & 5.3 \\
\hline 5 & $\mathrm{~L} 2 / \mathrm{L} 1$ & 61.5 & 65.0 & 175.0 & 97.5 & 5.3 \\
\hline 6 & PUTU-19/A G-27 & 59.0 & 62.0 & 160.0 & 85.0 & 5.6 \\
\hline 7 & AG-29/Pool-17 & 57.5 & 60.5 & 207.5 & 97.5 & 4.1 \\
\hline 8 & PUTU-17/A G 27 & 55.0 & 55.5 & 195.0 & 97.5 & 5.4 \\
\hline 9 & PUTU-12/A G-27 & 56.5 & 59.5 & 192.5 & 95.0 & 5.7 \\
\hline 10 & PUTU-10/Arun-2 & 59.0 & 62.0 & 167.5 & 90.0 & 5.3 \\
\hline 11 & L1/L3 & 63.0 & 66.5 & 162.5 & 72.5 & 6.4 \\
\hline 12 & L7/L6 & 63.5 & 66.5 & 130.0 & 62.5 & 3.0 \\
\hline 13 & AG-20/Pool-17 & 52.5 & 55.5 & 175.0 & 75.0 & 4.9 \\
\hline 14 & PUTU-20/A G-27 & 59.5 & 63.0 & 172.5 & 85.0 & 5.9 \\
\hline 15 & PUTU-4/Rampur Composite & 59.0 & 62.0 & 195.0 & 97.5 & 4.9 \\
\hline 16 & Gaurav & 58.0 & 61.0 & 190.0 & 92.5 & 5.4 \\
\hline 17 & Rajkumar & 53.0 & 60.5 & 182.5 & 82.5 & 5.7 \\
\hline \multirow[t]{5}{*}{18} & Pioneer30G10 & 66.5 & 70.0 & 170.0 & 77.5 & 0.4 \\
\hline & Grand mean & 58.77 & 50.417 & 178.056 & 87.50 & 5.023 \\
\hline & CV,\% & 8.29 & 15.82 & 12.50 & 19.15 & 18.85 \\
\hline & LSD0.05 & 10.275 & 20.186 & 47.315 & 35.349 & 1.999 \\
\hline & F-test & $*$ & $*$ & ns & ns & $*$ \\
\hline
\end{tabular}




\section{Conclusion}

Evaluation of hybrid maize is important task for hybrid development program. The observed variation on plant height and ear height were non significant but tasseling and silking along with grain yield were significantly differed among the tested hybrids in both years. The hybrids namely PUTU-19/AG-27, PUTU-20/AG-27, L3/L-2, L-1/L-3 and P UTU-9/AG-27 were found superior hybrids in terms of grain yield, so they should be promoted and tested on farms before release and recommendation for general cultivation in Terai region of Nepal.

\section{References}

[1] Ali Z. Studies on comparative economic returns of different maize genotypes. M.Sc. Thesis, Deptt. Agron., Univ. Agri., Faisalabad. 1994.

[2] McCutcheon J, Siegrist H, Rzenwncki P. Fair field, Licking, and Perry counties- osu. Extension commercial corn hybrid side by side performance trials. Special circular Ohio Agriculture Research and Development Center.2001, (179): 54-56.

[3] MOAC. Statistical information on Nepalese agriculture, Agribusiness Promotion and Statistics Division, Singhadarbar, Kathmandu, Nepal. 2007/2008, pp.127

[4] Russel F, Eisensmith S P. MSTAT-C. Crop \& Soil Sci. Deptt. Michigan State Univ. USA. 1983.

[5] Sharma D, C haudhary D, Yadav R. Hybrid maize development for highly potential production system of Nepal. Proceedings of the 24th National Summer Crops Research Workshop, 2004, pp. 38-45.

[6] Thapa R B, Dangol D R. A preliminary survey of weed flora at IAAS and its vicinity. In: F. P. Neupane (ed.) IAAS Research Report (1985-1991). Institute of Agriculture and Animal Science, Rampur, Chitwan, Nepal, 1988, pp. 59-65. 